\title{
DESAIN E-DIAGNOSTIC TEST UNTUK ANALISIS PEMAHAMAN KONSEP PADA MATERI REDOKS DAN TATA NAMA SENYAWA
}

\author{
Naila Faza Kamila ${ }^{1}$, Jumaeri ${ }^{2}$ \\ 1,2 Jurusan Kimia FMIPA Universitas Negeri Semarang \\ Gedung D6 Lantai 2 Kampus Sekaran Gunungpati Semarang, 50229, Telp. \\ (024)8508035
}

\begin{abstract}
Abstrak
Kesulitan belajar peserta didik dalam memahami konsep kimia perlu diidentifikasi dengan sebuah instrumen evaluasi yang tepat. Untuk itu penelitian ini bertujuan untuk mengetahui kelayakan dan keefektifan pengembangan instrumen e-diagnostic test berupa three tier multiple choice (TTMC) untuk menganalisis ketercapaian kompetensi dasar ranah kognitif dan pemahaman konsep. Instrumen tersebut terdiri dari tiga tingkat, yaitu: jawaban, alasan, dan keyakinan. Penelitian ini merupakan penelitian pengembangan dengan metode Plomp yang meliputi beberapa fase yaitu fase investigasi awal, desain, realisasi, tes dan evaluasi, serta implementasi. Subjek penelitian ini peserta didik kelas X SMA Islam Sultan Agung 1 Semarang. Hasil penelitian menunjukkan instrumen yang dikembangkan layak dengan hasil validasi isi oleh pakar dan validasi konstruk melalui uji skala kecil dan besar. Profil paham konsep tertinggi ditunjukkan oleh IKD-5 yaitu sebesar 61,02\%. Profil miskonsepsi tertinggi ditunjukkan oleh IKD-4 yaitu sebesar $69,49 \%$. Dan profil tidak paham konsep tertinggi ditunjukkan oleh IKD-3 yaitu sebesar 26,27\%. Hasil analisis profil pemahaman konsep secara keseluruhan pada materi redoks dan tata nama senyawa menunjukkan $37,85 \%$ peserta didik paham konsep, 43,84\% peserta didik miskonsepsi, dan $18,30 \%$ peserta didik tidak paham konsep.
\end{abstract}

Kata kunci: e-diagnostic test, redoks, pemahaman konsep

\begin{abstract}
The learning difficulties of students in understanding chemical concepts need to be identified with an appropriate evaluation instrument. For this reason, this study aims to determine the feasibility and effectiveness of developing an e diagnostic test instrument in the form of a three tier multiple choice (TTMC) to analyze the achievement of basic competencies in the cognitive domain and understanding concepts. The instrument consists of three levels, namely: answers, reasons, and beliefs. This research is a development research using the Plomp method which includes several phases, namely the initial investigation phase, design, realization, test and evaluation, and
\end{abstract}

Universitas Negeri Semarang

Email: nailafazakamila@gmail.com
(C2020 Universitas Islam Negeri Walisongo 177

ISSN: 2088-7868, e-ISSN 2502-5708 
implementation. The subjects of this study were students of class $\mathrm{X}$ SMA Islam Sultan Agung 1 Semarang. The results showed that the instrument developed was feasible with the results of content validation by experts and construct validation through small and large scale tests. The highest profile of conceptual understanding is shown by the IKD5 , which is $61.02 \%$. The highest misconception profile is shown by the IKD-4, which is $69.49 \%$. And the highest profile of not understanding the concept is shown by IKD-3 which is equal to $26.27 \%$. The results of the analysis of the overall concept understanding of the redox material and compound nomenclature showed that $37.85 \%$ of students understood concepts, $43.84 \%$ of students had misconceptions, and $18.30 \%$ of students did not understand concepts.

Keywords: e-diagnostic test, redox, conceptual understanding

\section{PENDAHULUAN}

Kemampuan kognitif ilmu pengetahuan alam atau sains merupakan salah satu bagian yang penting untuk dikaji dalam pendidikan di Indonesia. Konsep-konsep yang terdapat dalam sains bersifat kompleks termasuk pada pelajaran kimia. Namun peserta didik cenderung mengalami kesulitan saat pembelajaran kimia berlangsung. Hal ini disebabkan karena objek kimia yang bersifat abstrak, sifat materi kimia tidak mudah dipahami, citra pembelajaran kimia kurang baik (takut - tegang - bosan - banyak problem), kemampuan kognitif peserta didik masih konkret dan kurangnya motivasi belajar peserta didik (Juwairiyah, 2013). Selain itu kimia merupakan materi baru yang diajarkan di sekolah menengah atas. Peserta didik sekolah menengah atas sedang mengalami proses transisi dari cara berpikir konkrit menuju cara berpikir abstrak, yaitu mempelajari suatu fenomena yang tidak bisa diamati secara langsung. Kimia juga merupakan mata pelajaran sains yang berhubungan dengan pemahaman konsep dan rumus beserta pemecahan masalahnya (Afriawan, 2012). Salah satu bahasan dalam pelajaran kimia yaitu reaksi redoks yang bersifat abstrak, namun peserta didik dituntut untuk memahami terjadinya reduksi dan oksidasi tanpa melihat adanya serah terima elektron atau oksigen secara nyata. Selain itu materi redoks banyak menuntut kemampuan berhitung matematis dan keterikatan pemahaman konsep pada materi lain.

Pemahaman konsep merupakan kemampuan seseorang mengembangkan ide abstrak yang memungkinkannya untuk mengelompokkan/menggolongkan suatu objek. Setiap konsep bersifat berjenjang, hal ini dapat dilihat pada contoh konsep tentang fungsi 
bijektif yang dikembangkan dari konsep relasi dan sebagainya (Setiawan, 2008). Konsep disusun secara berurutan sehingga konsep sebelumnya akan digunakan untuk mempelajari konsep selanjutnya. Oleh sebab itu, belajar harus mengerti secara makna dan filosofinya, maksud dan implikasi serta aplikasinya, sehingga menyebabkan peserta didik memahami suatu situasi (Agustin, 2018). Keberhasilan peserta didik dalam memahami konsep yang lebih kompleks didasarkan pada pemahaman konsep dasar yang dikuasainya (Ulva, 2016).

Pemahaman konsep tersebut belum dapat dipastikan dari ketuntasan nilai yang diperoleh peserta didik. Hal tesrsebut dikarenakan evaluasi pembelajaran yang dilakukan belum semuanya dapat mendeteksi tingkat pemahaman konsep. Evaluasi yang biasa dilakukan adalah dengan ulangan harian, dimana kesalahan peserta didik dalam menjawab soal biasanya hanya dianggap sebagai kesalahan hitung, kurang teliti, atau karena kurang belajar. Namun guru tidak menemukan kemungkinan kesalahpahaman peserta didik pada konsep materi tersebut. Evaluasi pembelajaran dengan tes pilihan ganda lebih disukai karena soal pilihan ganda lebih mudah diterapkan, namun evaluator akan kesulitan dalam menentukan jawaban peserta didik tersebut menggambarkan tingkat kemampuannya ataukah jawaban tersebut hanya tebakan saja (Siswaningsih, 2014). Instrumen tes diagnostik tipe three-tiers multiple choice dianggap lebih efektif untuk menentukan pemahaman konsep maupun miskonsepsi peserta didik. Tes diagnostik adalah tes yang digunakan untuk mengetahui kekuatan dan kelemahan peserta didik ketika mempelajari sesuatu, sehingga hasilnya dapat digunakan sebagai dasar tindak lanjut. Instrumen tes three-tiers multiple choice merupakan instrumen tes yang paling valid, reliabel, dan akurat untuk mengidentifikasi pemahaman konsep maupun miskonsepsi peserta didik (Peşman \& Aryilmaz, 2010).

Tes diagnostik dengan Computer Based Test (CBT) memiliki kelebihan jika dibandingkan dengan tes manual yaitu dapat mengecek hasil pengerjaan soal secara otomatis, sehingga hasil tes dapat keluar lebih cepat. Kelebihan tes diagnostik three-tiers multiple choice dengan CBT dibandingkan dengan multiple choice konvensional salah satunya adalah mengurangi kesalahan dalam pengukuran, penggunaan multiple choice konvensional dengan lima pilihan jawaban memiliki kesempatan menjawab benar melalui cara menebak adalah $20 \%$ sedangkan jika menggunakan tes two-tier multiple choice kesempatan menjawab benar dengan cara menebak adalah $4 \%$. 
Berdasarkan paparan di atas maka guru perlu mengetahui tingkat pemahaman peserta didiknya agar dapat memberikan kebijakan untuk menindaklanjuti masalah tersebut baik dengan upaya remidiasi atau lainnya sehingga pembelajaran berikutnya akan lebih optimal hasilnya. Oleh karena itu, dibutuhkan adanya pengembangan instrumen untuk menganalisis pemahaman konsep peserta didik.

\section{METODE PENELITIAN}

Penelitian ini merupakan penelitian pengembangan yang bertujuan untuk mengetahui kelayakan dan keefektifan instrument $e$-diagnostic test yang dikembangkan untuk analisis ketercapaian kompetensi dasar aspek pengetahuan (kognitif) dan pemahaman konsep peserta didik pada materi redoks dan tata nama senyawa. Fase yang dilakukan terdiri dari lima langkah yaitu (1) fase investigasi awal, (2) fase desain, (3) fase realisasi, (4) fase tes, evaluasi, dan revisi, (5) fase implementasi (Plomp, 1997). Model prosedural Plomp dipilih karena merupakan model yang menggambarkan langkahlangkah prosedural yang harus diikuti secara bertahap dari awal sampai akhir untuk menghasilkan suatu produk tertentu. Subjek penelitian peserta didik kelas X MIPA SMA Islam Sultan Agung 1 Semarang yaitu kelas XI MIPA 2 dan XI MIPA 6.

Analisis dilakukan dengan pengelompokan jawaban menjadi tiga kategori, yaitu memahami, tidak memahami, dan miskonsepsi. Kemungkinan pola respon jawaban terhadap butir soal dapat dilihat pada Tabel 1.

Tabel 1. Pengkategorian Pola Jawaban Peserta Didik (Bayrak, 2013)

\begin{tabular}{|c|c|c|c|c|c|c|c|}
\hline No. & Kategori & Jawaban & Skor & Alasan & Skor & Keyakinan & Skor \\
\hline 1 & Memahami & Benar & 1 & Benar & 1 & Yakin & 1 \\
\hline \multirow[t]{4}{*}{2} & $\begin{array}{l}\text { Tidak } \\
\text { memahami }\end{array}$ & Benar & 1 & Benar & 1 & $\begin{array}{l}\text { Tidak } \\
\text { yakin }\end{array}$ & 0 \\
\hline & & Benar & 1 & Salah & 0 & $\begin{array}{l}\text { Tidak } \\
\text { yakin }\end{array}$ & 0 \\
\hline & & Salah & 0 & Benar & 1 & $\begin{array}{l}\text { Tidak } \\
\text { yakin }\end{array}$ & 0 \\
\hline & & Salah & 0 & Salah & 0 & $\begin{array}{l}\text { Tidak } \\
\text { yakin }\end{array}$ & 0 \\
\hline \multirow[t]{3}{*}{3} & Miskonsepsi & Salah & 0 & Salah & 0 & Yakin & 1 \\
\hline & & Salah & 0 & Benar & 1 & Yakin & 1 \\
\hline & & Benar & 1 & Salah & 0 & Yakin & 1 \\
\hline
\end{tabular}




\section{HASIL DAN PEMBAHASAN}

Penelitian ini diawali dengan fase investigasi awal yaitu mengumpulkan dan menganalisis informasi, definisi masalah, dan rencana lanjutan dari penelitian. Selain itu analisis silabus juga diperlukan sebagai dasar pengetahuan penilaian materi yang akan dilakukan. Selanjutnya adalah tahap desain, peneliti memulai desain instrumen $e$ diagnostic test berupa three-tiers multiple choice (TTMC) yang diawali dengan pembuatan kisi-kisi soal tentang materi pokok redoks dan tata nama senyawa sesuai dengan kompetensi dasar kurikulum 2013.

Berdasarkan kompetensi dasar 3.9. Menentukan bilangan oksidasi unsur untuk mengidentifikasi reaksi reduksi dan oksidasi serta penamaan senyawa kemudian dijabarkan sesuai indikator soal yang dikembangkan. Indikator kompetensi dasar tersebut adalah (1) Peserta didik dapat menguasai konsep reaksi oksidasi-reduksi ditinjau dari pengikatan dan pelepasan oksigen, pengikatan dan pelepasan elektron, serta peningkatan dan penurunan bilangan oksidasi, (2) Peserta didik dapat mengetahui reaksi redoks dan bukan reaksi redoks berdasarkan konsep reaksi redoks, (3) Peserta didik menguasai konsep bilangan oksidasi atom unsur dalam suatu senyawa atau ion, (4) Peserta didik dapat mengetahui unsur yang mengalami oksidasi (reduktor), unsur yang mengalami reduksi (oksidator), hasil oksidasi, dan hasil reduksi pada suatu reaksi redoks, (5) Peserta didik dapat menguasai konsep redoks untuk memecahkan permasalahan di kehidupan sehari-hari, (6) Peserta didik menguasai kaidah tata nama senyawa.

Selanjutnya pada tahap realisasi dilakukan pembuatan butir soal produk instrumen yang dikembangkan. Kemudian pada tahap tes, evaluasi, dan revisi instrumen yang telah dikembangkan dilakukan validasi kelayakan isi oleh pakar/ahli dan dilanjutkan revisi. Selain itu juga dilakukan validasi konstruk melalui uji skala kecil dan besar kemudian implementasi. Instrumen yang dikembangkan dilakukan uji validasi isi dan konstruk untuk mengetahui kelayakan instrument tersebut. Dari hasil data tersebut digunakan untuk menentukan validitas (kelayakan) instrumen yang dikembangkan (Setiawan, 2012). Hasil dari validasi isi pada pengembangan instrument $e$-diagnostic test ini disajikan pada Tabel 2. 


\begin{tabular}{lcccc}
\hline \multicolumn{1}{c}{ Aspek } & I & Total Skor Validator & Skor \\
& 10 & 9 & III & Maksimal \\
\hline Isi & 10 & 10 & 9 & 12 \\
Konstruksi & 7 & 6 & 9 & 12 \\
Bahasa & 27 & 25 & 6 & 8 \\
Total & Sangat valid & Valid & Valid & 32 \\
Keterangan & & & & \\
\hline
\end{tabular}

Berdasarkan Tabel 2 diketahui total skor ketiga aspek dari validasi ahli berturutturut adalah 27, 25 dan 24 dengan skor maksimal 32 yang menunjukan bahwa instrument tes tersebut dalam kriteria valid. Hasil penilaian menunjukan bahwa pakar memberikan respon baik dan instrument tes yang dikembangkan telah layak meskipun masih perlu adanya perbaikan pada beberapa soal untuk menyempurnakan produk. Dari hasil validasi dan saran dari para pakar/ahli maka selanjutnya peneliti melakukan revisi untuk memperbaiki instrument tes yang telah dikembangkan sesuai dengan koreksi dan saran yang diberikan. Pada uji validasi konstruk dilakukan uji skala kecil dan uji skala besar. Pengujian skala kecil digunakan untuk mengetahui keefektifan waktu pengerjaan soal. Hasil iji validitas empiris menggunakan IBM SPSS menunjukan bahwa 14 butir soal dinyatakan valid dan 16 soal lainya tidak valid. Dan reliabilitas instrument $e$-diagnostic test pada kedua uji tersebut sebesar 0,893 dan 0,859 sehingga produk yang dikembangkan memiliki kriteria reliabel. Dari hasil validasi tersebut kemudian butir soal yang sudah teruji valid kemudian diinput dalam program web e-project-tech.com.

Keefektifan instrument tes dapat diketahui melalui hasil analisis pemahaman konsep yang telah dikerjakan oleh peserta didik pada tahap implementasi. Efektivitas yaitu apabila tujuan-tujuan sasaran yang telah ditentukan sebelumnya dapat tercapai. Instrumen e-diagnostic test dikatakan efektif jika instrument tersebut efektif digunakan untuk mengetahui pemahaman konsep peserta didik (Kamilah, 2016). Sehingga hasil jawaban peserta didik kemudian digunakan untuk mengetahui keefektifan instrumen tes dengan analisis ketercapaian kompetensi dasar aspek kognitif dan pemahaman konsep peserta didik.

Hasil analisis profil pemahaman konsep peserta didik pada penelitian ini diklasifikasikan berdasarkan kombinasi jawaban pada soal e-diagnostic test. Profil pemahaman konsep peserta didik terdiri atas 3 jenis yaitu paham konsep, miskonsepsi, dan tidak paham konsep (Salirawati, 2011). Profil paham konsep per butir soal ditunjukkan pada Tabel 3 
Tabel 3. Profil Pemahaman Konsep Tiap Butir Soal

\begin{tabular}{ccccccc}
\hline $\begin{array}{c}\text { No } \\
\text { Soal }\end{array}$ & $\begin{array}{c}\text { Paham } \\
\text { Konsep }\end{array}$ & $\%$ & Miskonsepsi & $\%$ & $\begin{array}{c}\text { Tidak } \\
\text { Paham } \\
\text { Konsep }\end{array}$ & $\%$ \\
\hline 1 & 6 & 10,17 & 38 & 64,41 & 15 & 25,42 \\
2 & 26 & 44,07 & 21 & 35,59 & 12 & 20,34 \\
3 & 21 & 35,59 & 26 & 44,07 & 12 & 20,34 \\
4 & 21 & 35,59 & 16 & 27,12 & 22 & 37,29 \\
5 & 13 & 22,03 & 37 & 62,71 & 9 & 15,25 \\
6 & 6 & 10,17 & 45 & 76,27 & 8 & 13,56 \\
7 & 36 & 61,02 & 19 & 32,20 & 4 & 6,78 \\
8 & 21 & 35,59 & 29 & 49,15 & 9 & 15,25 \\
9 & 36 & 61,02 & 16 & 27,12 & 7 & 11,86 \\
10 & 20 & 33,90 & 21 & 35,59 & 18 & 30,51 \\
11 & 33 & 55,93 & 23 & 38,98 & 3 & 5,08 \\
12 & 33 & 55,93 & 15 & 25,42 & 11 & 18,64 \\
13 & 10 & 16,95 & 35 & 59,32 & 14 & 23,73 \\
14 & 29 & 49,15 & 21 & 35,59 & 9 & 15,25 \\
\hline
\end{tabular}

Instrument e-diagnostic test three tiers multiple choice (TTMC) digunakan untuk mendiagnosis profil pemahaman konsep peserta didik. Analisis untuk mengetahui profil pemahman konsep peserta didik dilakukan berdasarkan indikator kompetensi dasar (IKD). Analisis pemahaman konsep berdasarkan IKD bertujuan untuk mengetahui seberapa besar tingkat pemahaman konsep peserta didik dalam mencapai tujuan pembelajaran tersebut. Profil pemahaman konsep berdasarkan indikator kompetensi dasar (IKD) ditunjukkan pada Tabel 4.

Secara keseluruhan presentase profil paham konsep tertinggi ditunjukkan oleh IKD5 yaitu sebesar $61,02 \%$. Peserta didik dikatakan paham konsep jika dapat menjawab dengan benar, alasan pemilihan jawaban tepat dan yakin atas pilihan jawabanya. Profil miskonsepsi tertinggi ditunjukkan oleh IKD-4 yaitu sebesar 69,49\%. Peserta didik dikatakan miskonsepsi jika peserta didik dapat menjawab dengan benar salah satu atau bahkan tidak ada yang benar sama sekali pada pertanyaan tingkat pertama atau tingkat kedua, namun yakin terhadap jawaban yang dipilih. Dan profil tidak paham konsep tertinggi ditunjukkan oleh IKD-3 yaitu sebesar 26,27\%. Peserta didik dikatakan tidak paham konsep jika peserta didik tidak yakin dengan pilihan jawaban dari pertanyaan maupun alasan.

Tabel 4. Profil pemahaman konsep peserta didik 


\begin{tabular}{clcccc}
\hline No & \multicolumn{1}{c}{$\begin{array}{c}\text { Indikator Kompetensi } \\
\text { Dasar (IKD) }\end{array}$} & $\begin{array}{c}\text { Butir } \\
\text { Soal }\end{array}$ & $\begin{array}{c}\text { Paham } \\
\text { Konsep }\end{array}$ & $\begin{array}{c}\text { Mis } \\
\text { konsepsi }\end{array}$ & $\begin{array}{c}\text { Tidak } \\
\text { Paham } \\
\text { Konsep }\end{array}$ \\
\hline 1 & $\begin{array}{l}\text { Menguasai konsep reaksi } \\
\text { oksidasi reduksi }\end{array}$ & 8,10 & $34,74 \%$ & $42,37 \%$ & $22,88 \%$ \\
2 & $\begin{array}{l}\text { Menguasai konsep bilangan } \\
\text { oksidasi suatu unsur dalam } \\
\text { senyawa dan ion }\end{array}$ & $1,2,3$, & $36,44 \%$ & $45,76 \%$ & $17,80 \%$ \\
3 & $\begin{array}{l}\text { Mengetahui reaksi yang } \\
\text { termmasuk redoks dan } \\
\text { bukan redoks dan peran } \\
\text { suatu unsur dalam reaksi }\end{array}$ & 4 dan 14 & $42,37 \%$ & $31,35 \%$ & $26,27 \%$ \\
\hline $\begin{array}{l}\text { Mengetahui reaksi yang } \\
\text { termasuk reaksi } \\
\text { disproporsionasi }\end{array}$ & 5 dan 6 & $16,10 \%$ & $69,49 \%$ & $14,41 \%$ \\
\hline $\begin{array}{l}\text { Menguasai konsep redoks } \\
\text { untuk permasalah sehari- } \\
\text { hari }\end{array}$ & 9 & $61,02 \%$ & $27,12 \%$ & $11,86 \%$ \\
$\begin{array}{l}\text { Menguasai kaidah tata nama } \\
\text { senyawa }\end{array}$ & $7,12,13$ & $44,63 \%$ & $38,98 \%$ & $16,38 \%$ \\
\hline
\end{tabular}

Pada IKD-1 yang meliputi butir soal nomor 8 dan 10, profil pemahaman konsep tertinggi adalah miskonsepsi. Dari kedua butir soal tersebut profil miskonsepsi tertinggi ditunjukkan oleh butir soal nomor 8. Peserta didik yang mengalami miskonsepsi pada butir soal nomor 8 sebanyak 49,15\%. Soal nomor 8 merupakan soal jenjang C3 yang meminta peserta didik menentukan senyawa yang mengalami reaksi oksidasi pada reaksi pemanasan global. Senyawa $\mathrm{CH}_{4}$ yang mengalami oksidasi menurut konsep reaksi redoks berdasarkan kenaikan dan penurunan bilangan oksidasi. Senyawa $\mathrm{CH}_{4}$ mengalami kenaikan bilangan oksidasi pada unsur $\mathrm{C}$ dari -4 menjadi +4 dengan hasil oksidasi senyawa $\mathrm{CO}_{2}$. Jawaban tingkat pertama yang banyak dipilih oleh peserta didik adalah $\mathrm{CH}_{4}$ dan $\mathrm{O}_{2}$. Pada opsi tersebut masih kurang tepat karena pada $\mathrm{O}_{2}$ unsur $\mathrm{O}$ justru mengalami reduksi karena mengalami penurunan bilangan oksidasi dari 0 menjadi -2 . Cuplikan butir soal nomor 9 dapat dilihat pada Gambar 1. 


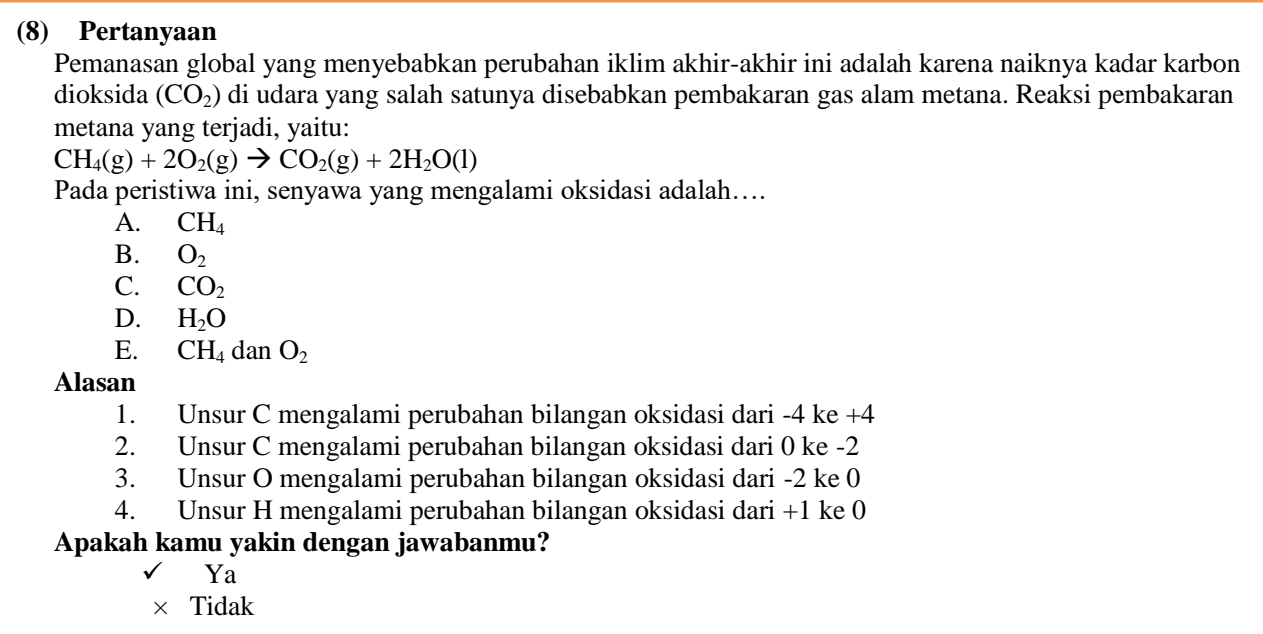

\section{Gambar 1. Cuplikan Butir Soal Nomor 8}

Pada IKD-2 yang meliputi butir soal nomor 1, 2, 3, dan 11, profil pemahaman konsep tertinggi yaitu miskonsepsi. Dari beberapa butir soal tersebut profil miskonsepsi tertinggi ditunjukkan oleh butir soal 1. Peserta didik yang mengalami miskonsepsi pada butir soal nomor 1 sebesar 64,41\%. Butir soal nomor 1 merupakan soal dengan jenjang C3 yang meminta peserta didik menentukan perubahan bilangan oksidasi yang terjadi pada unsur $\mathrm{Cr}$ dalam suatu reaksi. Perubahan biloks yang terjadi adalah unsur $\mathrm{Cr}$ dalam senyawa $\mathrm{K}_{2} \mathrm{Cr}_{2} \mathrm{O}_{7}$ dengan bilangan oksidasi +6 mengalami perubahan bilangan oksidasi menjadi +3 pada senyawa $\mathrm{CrCl}_{3}$. Kesalahan yang terjadi terbanyak pada alasan yang dipilih peserta didik belum bisa menjabarkan suatu senyawa menjadi ion penyusunya. Cuplikan butir soal nomor 1 dapat dilihat pada Gambar 2.

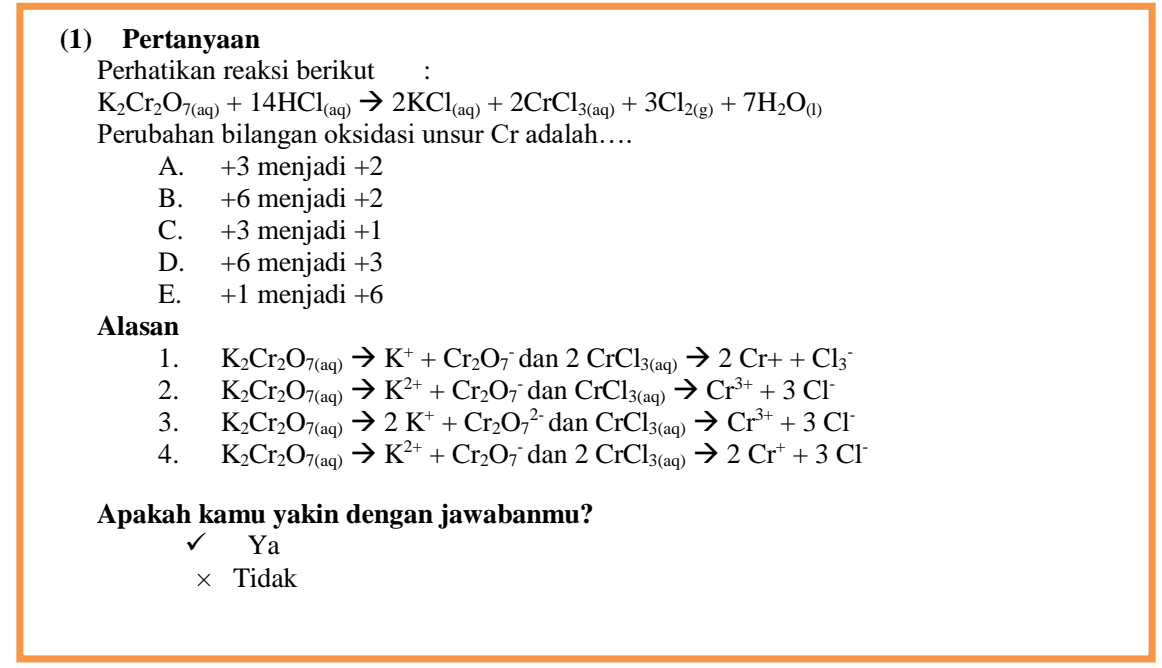

Gambar 2. Cuplikan Butir Soal Nomor 1 
Pada IKD-3 yang meliputi butir soal nomor 4 dan 14, profil pemahaman konsep tertinggi yaitu paham konsep. Dari kedua butir soal tersebut profil paham konsep tertinggi ditunjukkan oleh butir soal 14. Peserta didik yang mengalami paham konsep pada butir soal nomor 14 sebesar 49,15\%. Cuplikan soal nomor 14 dapat dilihat pada Gambar 3.

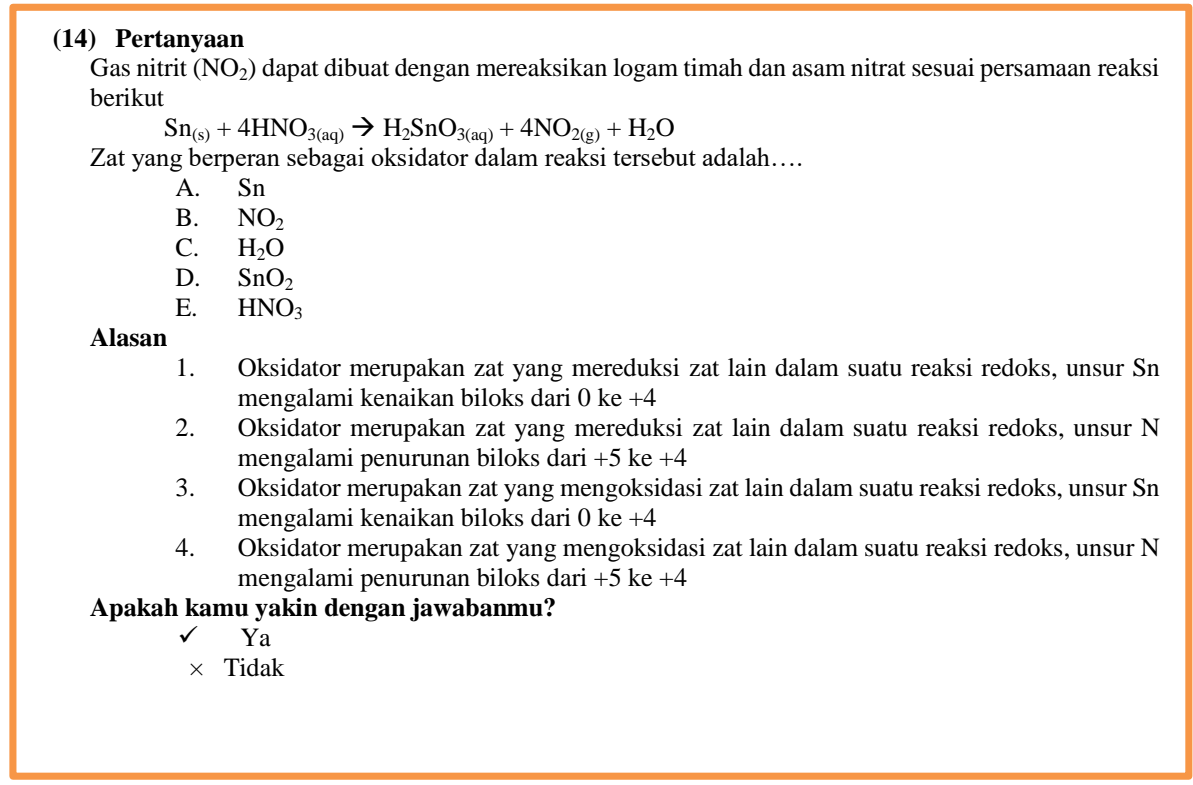

\section{Gambar 3. Cuplikan Butir Soal Nomor 14}

Butir soal nomor 14 merupakan soal dengan jenjang C3 peserta didik diminta untuk menentukan zat yang berperan sebagai oksidator dalam suatu reaksi. Pada soal tersebut unsur $\mathrm{N}$ dalam $\mathrm{HNO}_{3}$ mengalami penurunan bilangan oksidasi dari +5 menjadi +4 . Maka $\mathrm{HNO}_{3}$ menjadi zat senyawa yang berperan sebagai oksidator, dimana oksidator merupakan zat yang mengoksidasi zat lain dalam suatu reaksi redoks. Kesalahan pemahaman yang dialami oleh peserta didik kebnayakan mengenai konsep makna dari oksidator itu sendiri.

Pada IKD-4 yang meliputi butir soal nomor 5 dan 6, profil pemahaman konsep tertinggi yaitu miskonsepsi. Dari kedua butir soal tersebut, profil miskonsepsi tertinggi ditunjukkan oleh butir soal nomor 6. Peserta didik yang mengalami miskonsepsi pada butir soal nomor 6 sebesar 76,27\%. Cuplikan butir soal nomor 6 dapat dilihat pada Gambar 4. 


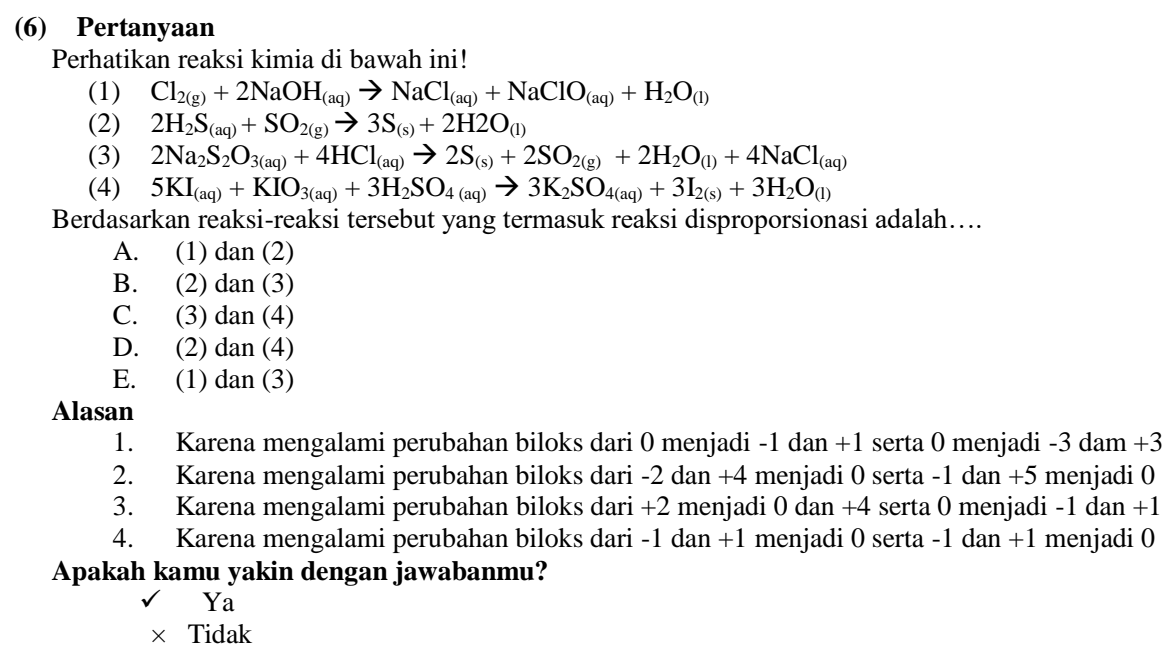

\section{Gambar 4. Cuplikan Butir Soal Nomor 6}

Butir soal nomor 6 merupakan soal dengan jenjang C4, dimana peserta didik diminta membedakan reaksi yang termasuk dalam reaksi disproporsionasi. Reaksi nomor $1, \mathrm{Cl}_{2}$ yang memiliki bilangan oksidasi 0 karena merupakan unsur bebas mengalami perubahan kenaikan sekaligus penurunan bilangan oksidasi. Kenaikan bilangan oksidasi yang terjadi dengan hasil oksidasi $\mathrm{NaClO}$ dimana $\mathrm{Cl}$ memiliki bilangan oksidasi +1 dan penurunan bilangan oksidasi yang terjadi dengan hasil reduksi $\mathrm{NaCl}$ dimana unsur $\mathrm{Cl}$ memiliki bilangan oksidasi -1. Pada reaksi nomor 3 senyawa $\mathrm{Na}_{2} \mathrm{~S}_{2} \mathrm{O}_{3}$ dimana unsur $\mathrm{S}$ memiliki bilangan oksidasi +2 mengalami perubahan kenaikan sekaligus penurunan bilangan oksidasi. Kenaikan bilangan oksidasi yang terjadi dengan hasil oksidasi $\mathrm{SO}_{2}$ dimana unsur $\mathrm{S}$ memiliki bilangan oksidasi +4 dan penurunan bilangan oksidasi yang terjadi dengan hasil reduksi $\mathrm{S}$ yang memiliki bilangan oksidasi 0 sebagai unsur bebas. Sedangkan pada reaksi nomor 2 dan 4 justru kebalikan dari reaksi disproporsionasi, dimana dari 2 zat reaktan dengan hasil reaksi yang sama mengalami reaksi reduksi dan oksidasi atau disebut komproporsionasi.

Pada IKD-5 yang meliputi butir soal nomor 9 dengan profil pemahaman konsep tertinggi adalah paham konsep. Profil paham konsep pada butir soal nomor 9 sebesar 61,02\% di mana butir soal ini merupakan soal dengan jenjang $\mathrm{C} 4$ yang meminta peserta didik menganalisis beberapa peristiwa dalam kehidupan sehari-hari dan memilih peristiwa yang bukan merupakan aplikasi dari konsep reaksi redoks. Di mana dari beberapa peristiwa yang bukan merupakan aplikasi dari reaksi redoks adalah pelarutan garam dapur, dimana reaksi dari pelarutan garam dapur adalah sebagai berikut: 
$\mathrm{NaCl}(\mathrm{s})+\mathrm{H}_{2} \mathrm{O}(\mathrm{l}) \rightarrow \mathrm{Na}^{+}(\mathrm{aq})+\mathrm{Cl}^{-}(\mathrm{aq})$. Dari reaksi tersebut dapat dilihat peristiwa pelarutan garam bukan merupakan reaksi redoks karena tidak terjadi perubahan bilangan oksidasi. Cuplikan butir soal nomor 9 dapat dilihat pada Gambar 5.

Kemampuan kognitif peserta didik untuk menganalisis suatu konsep dalam aplikasi di kehidupan sehari-hari perlu diperhatikan. Maka pada IKD ini bisa dijadikan sebuah rujukan seberapa peserta didik memahami konsep sehingga dapat memecahkan butir soal, sehingga dapat dijadikan data awal untuk mengambil tindak lanjut.

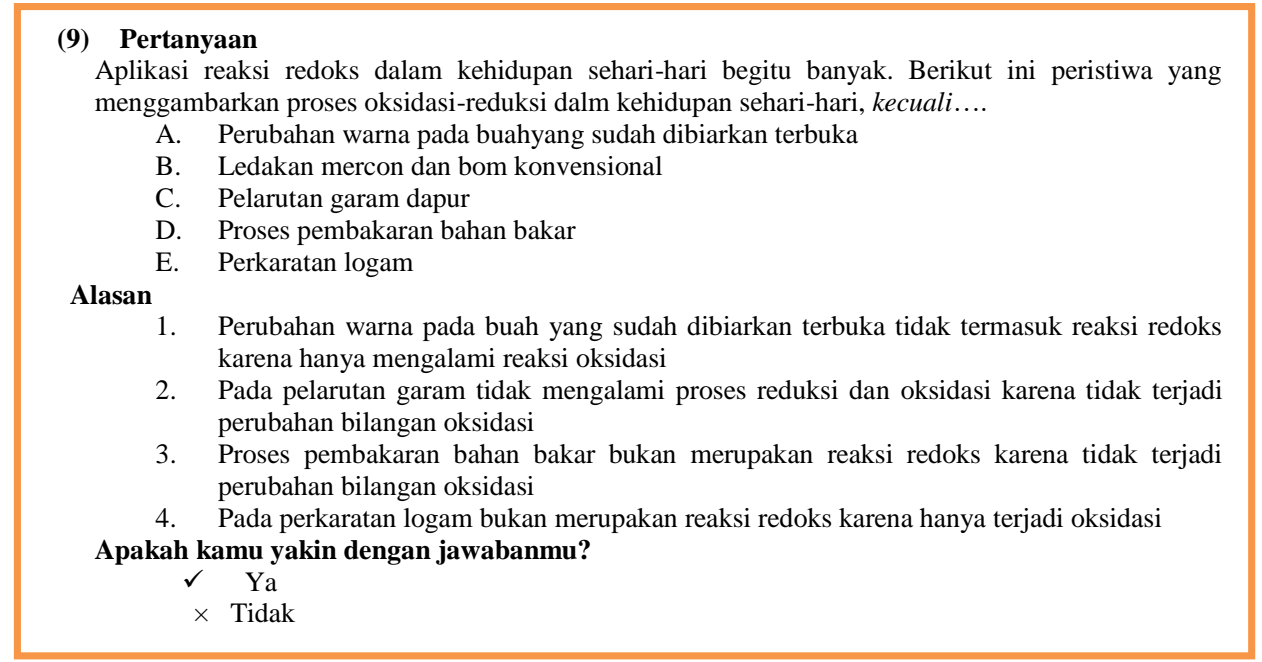

\section{Gambar 5. Cuplikan Butir Soal Nomor 9}

Pada IKD-6 yang meliputi butir soal nomor 7, 12, dan 13, profil pemahaman konsep tertinggi adalah paham konsep. Dari beberapa soal tersebut yang profil paham konsep tertinggi ditunjukkan oleh butir soal nomor 7. Butir soal nomor 7 merupakan butir soal dengan jenjang C2 dimana peserta didik diminta untuk menunjukan beberapa rumus kimia asam yang terdiri dari unsur halogen. rumus kimia dari asam hipoiodit, asam iodit, asam iodat, dan asam periodat berturut-turut adalah $\mathrm{HIO}, \mathrm{HIO}_{2}, \mathrm{HIO}_{3}$, dan $\mathrm{HIO}_{4}$. Presentase dari peserta didik yang paham konsep pada soal ini sebanyak $61,02 \%$. Cuplikan butir soal nomor 7 dapat dilihat pada Gambar 6. Berdasarkan analisis pemahaman konsep secara menyeluruh pada materi redoks dan tata nama senyawa, tingkat miskonsepsi peserta didik tergolong tinggi yaitu 42,52\%. Ada beberapa kemungkinan atas miskonsepsi yang terjadi pada peserta didik di antaranya karena peserta didik lebih mengutamakann aspek hafalan, terkecoh dengan jawaban dan alasan sehingga jawaban yang mereka pilih kurang tepat. 


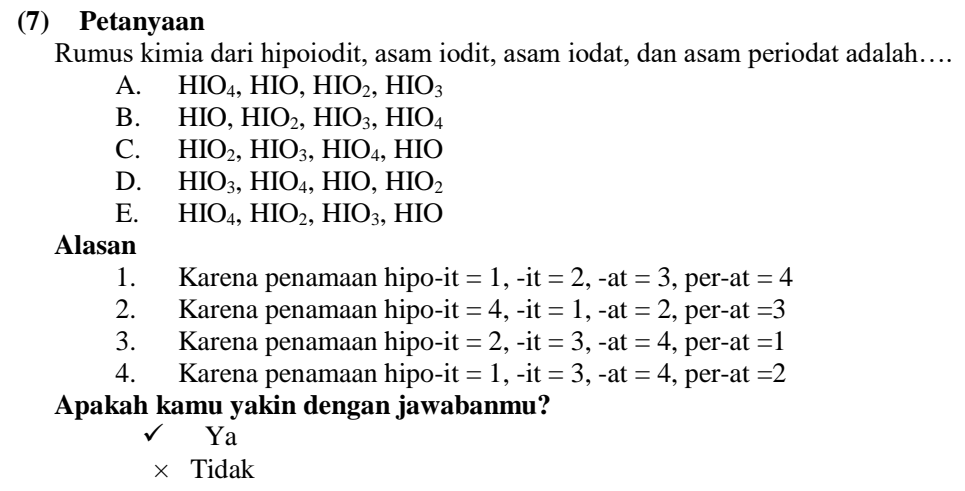

\section{Gambar 6. Cuplikan Butir Soal Nomor 7}

Data pendukung pada penelitian ini diberikan untuk mengetahui kepraktisan penggunaan produk. Instrumen yang diberikan berupa angket tanggapan guru dan peserta didik. Tanggapan peserta didik terhadap instrument $e$-diagnostic test TTMC tertinggi menunjukkan respon sangat setuju dengan presentase sebesar 57,63\%. Selebihnya menunjukkan presentase tanggapan setuju sebesar 40,68\% dan kurang setuju sebesar $1,69 \%$. Hal tersebut menunjukkan respon yang positif dari peserta didik dan dapat diartikan bahwa instrument e-diagnostic test TTMC yang dikembangkan dinilai praktis.

\section{SIMPULAN}

Berdasarkan penelitian yang telah dilakukan, dapat diperoleh simpulan yaitu: (1) instrumen e-diagnostic test layak digunakan sesuai dengan hasil analisis validasi isi oleh pakar/ahli dan validasi konstruk melalui uji skala kecil dan besar (2) instrumen $e$ diagnostic test efektif untuk digunakan analisis pemahaman konsep pada materi redoks dan tata nama senyawa. Profil paham konsep tertinggi ditunjukkan oleh IKD-5 yaitu sebesar $61,02 \%$. Profil miskonsepsi tertinggi ditunjukkan oleh IKD-4 yaitu sebesar 69,49\%. Dan profil tidak paham konsep tertinggi ditunjukkan oleh IKD-3 yaitu sebesar 26,27\%. Hasil analisis profil pemahaman konsep secara keseluruhan pada materi redoks dan tata nama senyawa menunjukkan 37,85\% peserta didik paham konsep, 43,84\% peserta didik miskonsepsi, dan 18,30\% peserta didik tidak paham konsep.

\section{DAFTAR RUJUKAN}


Agustin, A., Kasmadi, I., S., Wisnu, S. (2018). Pengaruh Penggunaan Peta Konsep Berbasis Multilevel Terhadap Pemahaman Konsep Kimia Peserta didik. Chemistry in Education. Semarang. CIE 7 (2) : 8-13.

Afriawan, M., Binadjab, A., dan Latifah, B. (2012). Pengaruh penerapan pendekatan SAVI bervisi SETS pada pencapaian kompetensi terkait reaksi redoks. Unnes science educational journal.

Bayrak, B.K. (2013). Using Two-Tier Test to Identify Primary Students' Conceptual Understanding and Alternative Conceptions in Acid Base. Mevlana International Journal of Education, 3 (2): 19-26.

BNSP. (2006). Permendiknas RI No. 22 Tahun 2006 tentang Standar Isi Untuk Satuan Pendidikan Dasar dan Menengah. Jakarta.

Juwairiah. (2013). Alat Peraga Dan Media Pembelajaran Kimia. Vol 04 No 01. JanuariJuni 2013, 5.

Kamilah, D. S., \& I. P. Suwarna. (2016). Pengembangan Three-Tier Test Digital Untuk Mengidentifikasi Miskonsepsi Pada Konsep Fluida Statis. Edusains, 8(2), 212-220.

Peşman, H., \& A. Aryilmaz. (2010). Development of A Three-Tier Test to Assess Ninth Grade Students' Misconceptions About Simple Electric Circuits. The Journal of Educational Research, 21(3), 208-222.

Plomp, Tj. (1997). Educational Design: Introduction Principles and Methods of Development Research. Norwell, MA: Kluwer Academic Publishers

Salirawati, D. (2011). Pengembangan Instrumen Pendeteksi Miskonsepsi Kesetimbangan Kimia pada Peserta Didik SMA. Penelitian Dan Evaluasi Pendidikan, 15(2), 232249.

Setiawan. (2008). Konsep Dan Makna Pembelajaran. Bandung: Alfabeta

Setiawan, D., E, Cahyono, \& C, Kurniawan. (2012). Identifikasi dan Analisis Miskonsepsi pada Materi Ikatan Kimia Menggunakan Instrumen Tes Diagnostik Three-Tier. Journal of Innovative Science Education, 1(1), 1-9.

Siswaningsih, W., Nur, A., Nuer, E., Indah, R. (2014). Pengembanangan Tes Diagnostik Three-tier Untuk Mengidentifikasi Miskonsepsi Pada Materi Kimia Peserta didik SMA. Jurnal Pengajaran MIPA. Bandung. Vol 19 No 1: 117-127.

Ulva, Y. I., Santosa, Parlan. (2016). Identifikasi Tingkat Pemahaman Konsep Larutan Penyangga Aspek Makroskopik, Submikroskopik, Dan Simbolik Pada Peserta didik Kelas XI IPA SMA N 3 Malang Tahun Ajaran 2013/2014. Jurnal Pembelajaran Kimia. Malang. Vol 01 No 02: 69-75. 